\title{
Linguodidactica KKI
}

DOI: $10.15290 /$ lingdid.2017.21.02

\author{
dr Agnieszka Andrychowicz-Trojanowska \\ Uniwersytet Warszawski \\ Wydział Lingwistyki Stosowanej \\ Instytut Komunikacji Specjalistycznej i Interkulturowej \\ tel. (22) 5534238 \\ e-mail: a.andrychowicz@uw.edu.pl
}

\section{GRUPA UCZNIOWSKA NA LEKCJI JĘZYKA ANGIELSKIEGO - WYZWANIE DLA NAUCZYCIELA}

\begin{abstract}
STRESZCZENIE
Popularne od lat 70. XX wieku podejście komunikacyjne postawiło w centrum zainteresowania ucznia, czego efektem jest wzrost znaczenia jego autonomii w nauczaniu i uczeniu się języka obcego. Z drugiej jednak strony, wciąż istotnym elementem procesu glottodydaktycznego pozostaje nauczyciel, kłóry ma obowiązek dbania o rozwój ucznia i wspierania go w nim. To znowu wiąże się z kwestią indywidualizacji procesu nauczania, szczególnie w odniesieniu do niektórych, bardziej wymagających, grup uczniowskich.

Zagadnienie autonomii ucznia oraz specjalnych potrzeb edukacyjnych jest szczególnie istotne dla dwóch grup uczniowskich, z którymi coraz częściej można spotkać się w trakcie pracy glottodydaktycznej w szkole, tj. uczniów ze zdiagnozowanq dysleksją oraz uczniów z zespołem Aspergera. Obydwie grupy wymagają indywidualnego podejścia, ale ich specyfika często wykracza poza podstawową wiedzę, z jaką nauczyciel, szczególnie ten młody, rozpoczyna pracę.
\end{abstract}

Słowa kluczowe: autonomia, indywidualizacja, uczeń, nauczyciel, dysleksja, zespół Aspergera

\section{SUMMARY}

\section{Students' group on the lesson of English - challenge for teacher}

Communicative language teaching that has been popular since the mid-70s situates a learner in the centre of scientific and research attention. The consequence of that is the growing importance of learner's autonomy during the process of teaching and learning a foreign language. On the other hand, a teacher is still an important element of the glottodidactic process - it is the teacher who is obliged to take care of the learner's development and progress and to support him or her in it. That is, though, connected with the individual approach to teaching, especially in relation to some more demanding groups of school students. 
The problem of learner's autonomy and of special educational needs is especially important for two school students groups that more and more often occur on the lessons of English, i.e. dyslectic students and the ones suffering from the Asperger syndrome. For both groups of students individual treatment and approach is crucial, but the specificity of both of them quite often goes beyond the knowledge a teacher, especially the young, non-experienced one, possesses.

Key words: autonomy, individualization, learner, teacher, dyslexia, Asperger syndrome

\section{Wstęp}

Od czasu reformy szkolnej z 1999 roku można mówić o prawdziwej podmiotowości polskiego ucznia w systemie edukacji. Jednym z celów tej reformy było kształtowanie takich wartości i postaw, które określają jakość życia i sens egzystencji człowieka, kształtowanie warunków sprzyjających rozwojowi osobowości, a w dalszej kolejności kształtowanie umiejętności i wiedzy. W związku z tym znacznie wzrosła rola takich kategorii jak podmiotowość i dialog ${ }^{1}$. Z drugiej jednak strony nauczyciele coraz częściej stają przed problemem indywidualizacji nauczania. Taki obowiązek w odniesieniu do uczniów ze specyficznymi trudnościami w uczeniu się nakłada na nich ustawodawca. Jednak w licznej grupie uczniów, biorącej udział $\mathrm{w}$ zajęciach lekcyjnych, trudne bywa pogodzenie autonomicznej roli ucznia i indywidualizacji pracy z nim z efektywną realizacją zapisów podstawy programowej.

Ze względu na aktualność i wagę powyższego zagadnienia na kolejnych stronach w zwięzły i dość ogólny sposób przypomnę zagadnienie autonomii ucznia, a następnie zwrócę uwagę na dwie grupy uczniowskie, które następnie krótko scharakteryzuję. Z grupami tymi coraz częściej spotykam się w trakcie pracy glottodydaktycznej w szkole. Obydwie one wymagają indywidualnego podejścia, a ich specyfika często wykracza poza podstawowe przygotowanie i wiedzę nauczyciela.

\section{Autonomia ucznia na lekcji języka angielskiego}

Ponad 40 lat temu, w połowie lat 70. ubiegłego wieku, wykształciło się nowe podejście do nauki języków obcych - podejście komunikacyjne (ang. communicative language teaching, CLT), na którym bazuje większość opracowywanych obecnie programów nauczania i dostosowanych do nich materiałów glotto-

1 E. Zawadzka, Nauczyciele języków obcych w dobie przemian, Kraków 2004, s. 19. 
dydaktycznych, w tym podręczników. Na bazie tego podejścia ukształtowały się także nowe obszary badawcze, jak choćby te dotyczące wspomagania uczniów w osiąganiu przez nich sprawności komunikacyjnej w języku obcym, odpowiednich sylabusów, programów nauczania, aktywności wykonywanych w klasie $w$ trakcie lekcji języka obcego, materiałów glottodydaktycznych. Ponadto od tego czasu uwaga badaczy koncentruje się przede wszystkim na osobie ucznia, jego autonomii, strategiach nauki języka obcego, motywacji, podstawowych sprawnościach językowych itp.

Przeniesienie środka ciężkości z nauczyciela na ucznia skutkuje zmianą roli, jaką pełni nauczyciel - bo oto staje się on kimś w rodzaju przewodnika, który ma za zadanie przeprowadzić ucznia przez trudny proces uczenia się, pomagając mu w pokonywaniu niemożliwych do uniknięcia trudności napotykanych w trakcie pracy nad systemem języka obcego ${ }^{2}$. Uczeń natomiast sam w decydujący sposób wpływa na przebieg i wyniki procesu uczenia się, który w niewielkim tylko stopniu podlega oddziaływaniu z zewnątrz ${ }^{3}$. Na tym właśnie polega autonomia osoby uczącej się, czyli świadome uczestnictwo tej osoby w procesie nauczania, czemu służy swoboda wyboru metody i konkretnych strategii przyswajania wiedzy ${ }^{4}$ Ta autonomia ucznia jest więc odpowiedzialnością ucznia za proces uczenia się, w którym uczeń uczestniczy, i to w klasie, jak również poza nią, na poziomie świadomości (dlaczego się uczę?) oraz umiejętności samodzielnego uczenia się i monitorowania swoich postępów ${ }^{5}$. Autonomia ucznia jest elementem jak najbardziej pozytywnym i wartościowym, jednak zbytnie absolutyzowanie jej grozi zderzeniem samodzielności ucznia z profesjonalną rolą nauczyciela (lidera procesu dydaktycznego) ${ }^{6}$. W kontekście nauki języków obcych autonomia ucznia oznacza również konieczność konsekwentnego utrwalania wiedzy zdobytej na kursie językowym czy w klasie na zajęciach szkolnych z języka obcego ${ }^{7}$.

Materiały dydaktyczne w podejściu komunikacyjnym służą prowokowaniu samodzielnych wypowiedzi. Podręczniki, których celem jest kształtowanie postawy autonomicznej uczniów, powinny mieć zatem charakter aktywizujący, wspomagający, transparentny, otwarty, naturalny, obiektywizujący, moty-

2 J. Arabski, Przedmowa, [w:] Nowe tendencje w glottodydaktyce, J. Arabski (red.), Katowice 1998, s. 5.

3 S. Chudak, Refleksja nad uczuciami i emocjami towarzyszacymi procesowi uczenia się a podręczniki do nauki języków obcych, „Lingwistyka Stosowana” 2011, 4, s. 251-266.

4 N. Pater-Ejgierd, Kultura wizualna a edukacja, Poznań 2010, s. 92.

5 D. Gabryś, Autonomia ucznia w procesie uczenia się języka obcego (badania kwestionariuszowe), [w:] Nowe tendencje w glottodydaktyce, J. Arabski (red.), Katowice 1998, s. 20, por. A. Michońska-Stadnik, Strategie uczenia się i autonomia ucznia w warunkach szkolnych, Wrocław 1996.

6 M. Dakowska, O rozwoju dydaktyki języków obcych jako dyscypliny naukowej, Warszawa 2014, s. 38.

7 A. Michońska-Stadnik, Strategie uczenia się i autonomia..., op. cit., s. 9-10. 
wujący $^{8}$. W tym kontekście szczególnie istotna jest orientacja w podręczniku, przenoszenie na uczniów odpowiedzialności za decyzje związane z procesem uczenia się, refleksje nad sposobem uczenia się oraz inne aspekty związane z przyswajaniem podsystemów języka, rozwijaniem sprawności językowych i regulowaniem procesu uczenia się .

Z punktu widzenia autonomii ucznia istotne są również różnice indywidualne pomiędzy uczniami, mające wpływ na przebieg i wydajność procesu przyswajania języka. Ta propagowana i postulowana autonomia ucznia powoduje konieczność poświęcania uwagi strategiom uczenia się, które mają bezpośredni związek z efektywnością uczenia się np. języków obcych ${ }^{10}$. W związku z tym nauczyciel języków obcych (ale również każdy inny nauczyciel) ma obowiązek dostosowywania odpowiednich technik (uznanych przez metodykę, lingwistykę, psychologię) do potrzeb konkretnego ucznia (techniki te związane są na przykład $\mathrm{z}$ indywidualnym stylem uczenia się, będącym wynikiem funkcji poznawczych jednostki; cechami osobowościowymi, doświadczeniem i wiedzą), tak aby w pełni realizować zasadę indywidualizacji w nauczaniu ${ }^{11}$. Oznacza to, że na płaszczyźnie psychologiczno-pedagogicznej nauczyciel języka obcego (jak i każdy inny nauczyciel) powinien sprzyjać rozwijaniu samodzielności i autonomii ucznia, wspomagać go w realizacji jego strategii uczenia się, wspierać budowanie poczucia własnej wartości, ograniczać i likwidować napięcia emocjonalne, motywować do działania ${ }^{12}$.

Jednak dostosowywanie sposobu pracy do potrzeb każdego indywidualnego ucznia, szczególnie w dość licznej grupie, jest zadaniem trudnym i wymagającym dużego zaangażowania samego nauczyciela, a także rozległej wiedzy. Nauczyciel musi poznać uczniów, ale również niejednokrotnie nieustannie poszerzać swoją wiedzę tak, aby móc sprostać stawianym przed nim wymaganiom i oczekiwaniom nie tylko dyrekcji szkoły i rodziców, ale przede wszyst-

8 C. Gick, Fördern Lehrwerke die Autonomie der Lerner?, [w:] Autonomes und partnerschaftliches Lernen. Modelle und Beispiele aus dem Fremd-sprachenunterricht (Sammel band), M. Müller, L. Wertenschlag, J. Wolff (red.), Berlin 1989, s. 163-185, za S. Chudak, Refleksja nad uczuciami i emocjami..., op. cit., s. 257.

9 S. Chudak, Refleksja nad uczuciami i emocjami..., op. cit.

10 J. Zybert, Strategie uczenia się języka obcego i nauczyciel, [w:] Nauczanie języków obcych w zreformowanej szkole, H. Komorowska (red.), Warszawa 2000, s. 143-151.

11 K. Jaworska-Biskup, Strategie kognitywne i metakognitywne w nauczaniu języka obcego uczniów ze specyficznymi trudnościami w czytaniu i pisaniu, [w:] Rola językoznawstwa w metodyce nauczania języka obcego, H. Kardela, T. Zygmunt (red.), Chełm 2007, s. 91-97.

12 M. Jaworska, Uczeń ze specyficznymi trudnościami w uczeniu się na lekcji języka obcego a ocenianie, „Języki Obce w Szkole" 2013, 4, s. 84; por. M. Jaworska, Nauka języka obcego jako czynnik stymulujący i ułatwiający korygowanie zaburzeń związanych ze specyficznymi trudnościami w uczeniu się, [w:] Trudności w czytaniu i pisaniu - rozważania teoretyczne i praktyczne, I. Pietras (red.), Warszawa 2012, s. 132-147. 
kim tego konkretnego ucznia. Ponadto nauczyciel ma ustawowy obowiązek m.in. rzetelnego realizowania zadań związanych z powierzonym mu stanowiskiem, a także z podstawowymi funkcjami szkoły, tj. funkcją dydaktyczną, wychowawczą i opiekuńczą, ma obowiązek dbania o kształtowanie u uczniów postaw moralnych i obywatelskich, a także, co jest najistotniejsze w kontekście niniejszego artykułu, ma obowiązek wspierania każdego ucznia w jego rozwoju ${ }^{13}$.

Na podstawie mojego wieloletniego doświadczenia pracy z grupami uczniowskimi $\mathrm{w}$ jednym $\mathrm{z}$ liceów ogólnokształcących mogę stwierdzić, że grupy te nie są i najprawdopodobniej nigdy nie będą homogeniczne. Różnice między uczniami występują na każdej płaszczyźnie, poczynając od pochodzenia, sytuacji rodzinnej (z mojej praktyki wynika, że nierzadko sytuacja ta jest skomplikowana), sytuacji materialnej, zainteresowań, ale również uzdolnień i ewentualnych specjalnych potrzeb edukacyjnych. Zapewne większość praktykujących nauczycieli (na dowolnym etapie edukacji) wymieni wśród cech różnicujących grupy uczniowskie te wskazujące na trudności w przyswajaniu materiału czy pracy na lekcji, często związane np. $\mathrm{z}$ dysleksją ${ }^{14}$. Jednak nie można zapominać także o całkiem sporej grupie uczniów z zespołem Aspergera czy często powiązanym $z$ dysleksją zespołem nadpobudliwości psychoruchowej (ADHD).

\section{Specjalne potrzeby edukacyjne - wybrane grupy uczniowskie}

W literaturze glottodydaktycznej kwestie związane z osobą ucznia są dość obszernie opisane. Charakterystyka ucznia i różne typologie są istotne z punktu widzenia zrozumienia przebiegu procesu dydaktycznego, a przede wszystkim jego (nie)powodzeń. W tym miejscu jednak skupię uwagę na kwestiach dotyczących uczniów ze specjalnymi potrzebami edukacyjnymi, ponieważ tacy uczniowie coraz częściej funkcjonują w jednej grupie uczniowskiej.

O specjalnych potrzebach edukacyjnych mówi się w odniesieniu do uczniów, którzy w okresie edukacji szkolnej wymagają odpowiadających ich indywidualnym możliwościom i ograniczeniom szczególnych warunków. Od drugiej połowy lat siedemdziesiątych XX wieku znaczącej zmianie uległa w Polsce sytuacja uczniów ze specyficznymi trudnościami w uczeniu się. Od tego czasu uczniowie ci mają prawnie zagwarantowaną możliwość uzyskania pomocy zarówno w szkole, jak i w specjalistycznych poradniach. Równolegle jednak zmieniają się także oczekiwania pod adresem nauczycieli. Uczniowie ze specyficz-

13 Ustawa z dnia 26 stycznia 1982 r. „Karta Nauczyciela”, Dz. U. z 2016 r. poz. 1379.

14 Por. A. Andrychowicz-Trojanowska, Materiał glottodydaktyczny w podręczniku do nauki języka angielskiego dla szkót średnich a jego odbiorca, „Lingwistyka Stosowana” 2015, 14, s. 1-15. 
nymi trudnościami w uczeniu się zostali włączeni do szerokiej grupy uczniów ze specjalnymi potrzebami edukacyjnymi, czego konsekwencją jest, oprócz uzyskania przez nich prawa do dostosowanej do ich możliwości i ograniczeń, specjalistycznej pomocy, nałożenie na nauczyciela obowiązku świadczenia pomocy psychologiczno-pedagogicznej. Udzielanie takiej pomocy przez nauczyciela zostało więc rozszerzone $\mathrm{z}$ uczniów ze specyficznymi trudnościami w uczeniu się na wszystkich uczniów niepełnosprawnych, niezależnie od ich różnorodnych potrzeb edukacyjnych ${ }^{15}$.

Do grupy uczniów ze specjalnymi potrzebami edukacyjnymi zalicza się zatem uczniów niepełnosprawnych intelektualnie, fizycznie, uczniów o niższej niż przeciętna inteligencji, uczniów z wadami narządów zmysłu (wzroku i słu$\mathrm{chu}$ ), zaburzeniami mowy, a także wspominanych już uczniów ze specyficznymi trudnościami w uczeniu się. Do grupy tej są czasem zaliczani także uczniowie wybitnie zdolni, którzy potrzebują większej samodzielności, trudniejszego materiału, szybszego tempa pracy, mniejszej liczby powtórek itp. ${ }^{16}$ Sytuacja prawna uczniów o specjalnych potrzebach edukacyjnych jest regulowana rozporządzeniami Ministra Edukacji Narodowej (np. zgodnie z Rozporządzeniem z dnia 7 września 2004 roku $^{17}$ ocena szkolna nie jest tylko odzwierciedleniem wiedzy - jest ona również uzależniona od możliwości ucznia, nie tylko w trakcie egzaminów, ale także podczas codziennej oceny osiągnięć uczniów. Ocena taka powinna uwzględniać możliwości ucznia, jego zdolności, ale również ograniczenia).

Specyficzne trudności w uczeniu się, a - co za tym idzie - specjalne potrzeby edukacyjne obserwowane są np. u uczniów z dysleksją (należy odróżnić dysleksję rozwojową, o której jest tu mowa, od dysleksji nabytej, czyli utraty umiejętności czytania przez osoby, które wcześniej taką umiejętność posiadały, ale na skutek wypadku, udaru, wylewu itp. doznały organicznego uszkodzenia mózgu, w rezultacie czego umiejętność tę utraciły) czy ze wspomnianym już zespołem Aspergera ${ }^{18}$. Właśnie te dwie grupy uczniów wymagają od nauczyciela zindywidualizowanego podejścia i pomocy $\mathrm{w}$ trakcie nauki $\mathrm{w}$ szkole.

K. Sochacka, Specjalne potrzeby i specyficzne trudności, [w:] Z problematyki kształcenia językowego, E. Awramiuk (red.), t. IV, Białystok 2012, s. 179-194.

16 M. Bogdanowicz, A. Adryjanek, Uczeń z dysleksją w szkole - poradnik nie tylko dla polonistów, Gdynia 2005, s. 12; por. M. Bogdanowicz, A. Adryjanek, M. Rożyńska, Uczeń z dysleksją w domu. Poradnik nie tylko dla rodziców, Gdynia 2007, s. 91; A. Andrychowicz-Trojanowska, Materiał glottodydaktyczny w..., op. cit.

17 Rozporządzenie Ministerstwa Edukacji Narodowej i Sportu z dnia 7 września 2004 roku w sprawie warunków i sposobu oceniania, klasyfikowania i promowania uczniów oraz przeprowadzania sprawdzianów i egzaminów w szkołach publicznych, Dz. U. z 2004, nr 199, poz. 2046 z późniejszymi zmianami.

18 A. Andrychowicz-Trojanowska, Materiat glottodydaktyczny w..., op. cit. 


\subsection{Dysleksja rozwojowa}

Dysleksja rozwojowa, rozumiana jako specyficzne trudności w czytaniu i pisaniu (przy jednoczesnym prawidłowym rozwoju umysłowym) ${ }^{19}$, jest coraz częściej diagnozowana u uczniów i nie pozostaje bez wpływu na sposób pracy ucznia.

Dysleksja $^{20}$ figuruje w międzynarodowych klasyfikacjach chorób i zaburzeń, np. w obowiązującej w Europie Międzynarodowej Statystycznej Klasyfikacji Chorób i Zaburzeń (International Statistical Classification of Diseases and Related Health Problems) jako ICD-10 („specyficzne rozwojowe zaburzenia umiejętności szkolnych”) i w klasyfikacji amerykańskiej (Diagnostic and Statistic Manual of Mental Disorders) jako DSM-IV (,zaburzenia uczenia się" $)^{21}$.

Dysleksja rozwojowa nie jest chorobą - ma podłoże neurobiologiczne i jest powiązana z budową i funkcjonowaniem mózgu ${ }^{22}$. Badania kliniczne z zakresu neurobiologii, neurofizjologii i psychofizjologii pokazują, że przyczyną dysleksji nie są zaburzenia wzroku i słuchu, upośledzenie umysłowe, brak motywacji do nauki czytania czy też niewłaściwe metody nauczania ${ }^{23}$. Często dysleksji, tj. specyficznym trudnościom w nauce czytania, towarzyszą trudności w zakresie czynności pisania (dysgrafia) i poprawnej pisowni (dysortografia) ${ }^{24}$. Dysleksja może być także powiązana z dysfazją (zaburzenia procesu nabywania zdolności mówienia i/lub rozumienia), dyskalkulią (specyficzne zaburzenia zdolności arytmetycznych), dyspraksją (niezborność ruchów), z problemami z zachowaniem kolejności czasowej (dyschronia), z orientacją przestrzenną i kierunkową, nadpobudliwością ruchową (o czym będzie mowa w końcowej części rozdziału), czy zaburzeniami uwagi itp. ${ }^{25}$

Obraz dysleksji jest zróżnicowany inter- oraz intraindywidualnie. Zróżnicowanie interindywidualne oznacza, że dysleksja u każdej dotkniętej nią

19 M. Bogdanowicz, A. Adryjanek, Uczeń z dysleksja w szkole..., op. cit., s. 24.

20 W niniejszym artykule wymiennie używam określenia dysleksja rozwojowa bądź dysleksja na oznaczenie tego samego.

21 M. Bogdanowicz, Specyficzne trudności w czytaniu i pisaniu w świetle klasyfikacji medycznych, psychologicznych i pedagogicznych, "Audiofonologia” 1997, t. X, s. 145-157.

22 Mini-max O DYSLEKSJI, czyli minimum tego, co na ten temat powinni wiedzieć rodzice i nauczyciele ucznia dyslektycznego, by maksymalnie mu pomóc, D. Mielcarek (red.) Warszawa 2006, s. 10, por. M. Habib, The neurological basis of developmental dyslexia. An overview and working hypothesis, "Brain” 2000, 123, s. 2373-2399.

23 A. Jurek, Języki obce w nauczaniu uczniów z dysleksją rozwojową. Część I, "Języki Obce w Szkole” 2004, 1, s. $67-72$.

24 J. Mickiewicz, Dysleksja rozwojowa. Podstawy diagnozy i terapii, Torun 2011.

25 M. Habib, The neurological basis..., op. cit., s. 2374. 
osoby może być inna, na co może mieć wpływ także płeć. Zróżnicowanie intraindywidualne dotyczy dynamiki dysleksji w ciągu życia dotkniętej nią osoby ${ }^{26}$.

Ze względu na coraz większą świadomość występowania tego zaburzenia oraz coraz głębszą wiedzę na jego temat dzieci w pierwszej klasie szkoły podstawowej badane są pod kątem ryzyka dysleksji, co pozwala na wyodrębnienie tych spośród nich, które są dysleksją zagrożone i udzielenie im odpowiednio wcześniej pomocy (poprzez wspieranie rozwoju psychoruchowego, usprawnianie funkcji rozwijających się z opóźnieniem, ewentualnie badania diagnostyczne w poradni psychologiczno-pedagogicznej $)^{27}$. Co istotne, objawy dysleksji wraz $\mathrm{z}$ wiekiem zmieniają się i raczej nie znikają samoistnie ${ }^{28}$.

Każdy uczeń z dysleksją jest inny, ponieważ każdy ma nieco inne symptomy dysleksji i, co za tym idzie, swój indywidualny profil poznawczy ${ }^{29}$ i indywidualne potrzeby. Dlatego też podstawą nauczania uczniów z dysleksją jest indywidualizowanie wymagań ${ }^{30}$. W związku z powyższym nauczyciel powinien zapoznać się z opinią i zaleceniami poradni psychologiczno-pedagogicznej na temat każdego ucznia z dysleksją, a także powinien dostosować swoje wymagania (sposób weryfikacji wiadomości, metody i formy pracy z uczniem, sposób oceniania) do indywidualnych potrzeb i możliwości takiego ucznia ${ }^{31}$. Natomiast uczeń z głęboką dysleksją rozwojową może zostać zwolniony z nauki drugiego języka obcego ${ }^{32}$.

Od lat 90. ubiegłego wieku zwracana jest uwaga na bardzo częste współwystępowanie dysleksji rozwojowej i $\mathrm{ADHD}^{33}$. ADHD (ang. attention deficyt/hyperactivity disorder, pol. zespół nadpobudliwości psychoruchowej z de-

G. Krasowicz-Kupis, Psychologia dysleksji, Warszawa 2008.

B. Lech, Wspieranie rozwoju dziecka ze specyficznymi trudnościami w nauce czytania i pisania, [w:] Dysleksja rozwojowa. Organizowanie sytuacji edukacyjnej ucznia w szkole $i$ w rodzinie, A. Giermakowska (red.), Kielce 2012, s. 339-347.

K. Bogdanowicz, Dysleksja a nauczanie języków obcych. Przewodnik dla nauczycieli i rodziców uczniów $z$ dysleksja, Gdańsk 2011.

Ibidem, s. 91-92.

Ibidem.

K. Grzela, Uczeń z dysleksją a nauka języka obcego, [w:] Dysleksja rozwojowa. Organizowanie sytuacji edukacyjnej ucznia w szkole $i$ w rodzinie, A. Giermakowska (red.), Kielce 2012, s. 387-395.

Rozporzadzenie MEN z dnia 30 kwietnia 2017 ze zmianami z 17 listopada 2010 r., Dz. U. nr 228 w sprawie warunków $i$ sposobu oceniania, klasyfikowania i promowania uczniów i stuchaczy oraz przeprowadzania sprawdzianów i egzaminów w szkołach publicznych, Dz. U. 2010 nr 228 poz. 1491.

Por. np. R.A. Dykman, P.T. Ackerman, Attention deficit disorder and specific reading disability: Separate but often overlapping disorders, „Journal of Learning Disabilities” 1991, 24, s. 96-103; E.G. Willcutt, B.F. Pennington, Psychiatric Comorbidity in Children and Adolescents with Reading Disability, "Journal of Child Psychology and Psychiatry" 2000, 41(8), s. 1039-1048. 
ficytem uwagi) nie jest zaburzeniem uczenia się, jednak skutecznie utrudnia „nabywanie sprawności szkolnych"34. Charakterystyczne dla zespołu nadpobudliwości psychoruchowej z zaburzeniami koncentracji uwagi jest niemożność trwałej uwagi, nadmierna i trudna do opanowania ekspresja ruchowa, a także znaczna impulsywność. Zachowania te mają charakter trwały, są organicznie zdeterminowanymi zaburzeniami rozwojowymi ośrodkowego układu nerwowego ${ }^{35}$. Niestety jednak określenie dziecko nadpobudliwe jest często nadużywane, co wiąże się również z faktem, że nie ma testów, które pozwalałyby diagnozować ADHD. Ponadto niektórzy specjaliści poddają w wątpliwość występowanie takiego zaburzenia.

Mimo że uczniów z dysleksją przybywa, to, jak zauważają badacze na podstawie analizy programów nauczania języków obcych, jakie zostały zatwierdzone przez MENiS (obecnie MEN) oraz poradników metodycznych dla nauczycieli, w opracowaniach tych $\mathrm{w}$ zasadzie w ogóle nie wspomina się o problemie pracy z uczniem z dysleksją, a jeśli już temat ten zostanie poruszony, to autorzy popełniają w tej kwestii dużo błędów merytorycznych ${ }^{36}$.

\subsection{Zespół Aspergera}

Zespół Aspergera został wpisany w 1992 roku do systemu klasyfikacyjnego ICD-1037 (Międzynarodowa klasyfikacja chorób i problemów zdrowotnych, International Statistical Classification of Diseases and Related Health Problems) Światowej Organizacji Zdrowia (WHO) ${ }^{38}$. Zarówno w klasyfikacji WHO 1992, jak i APA (American Psychiatric Association) 1994 zaburzenie to zostało zaliczone do całościowych zaburzeń rozwoju ${ }^{39}$.

Zespół Aspergera jest najłagodniejszą formą autyzmu, dotyczącą przede wszystkim zaburzeń funkcjonalnych ${ }^{40}$. Innymi słowy, zespół Aspergera jest za-

34 M. Lipowska, Dysleksja i ADHD. Wspótwystępujące zaburzenia rozwoju. Neuropsychologiczna analiza deficytów pamięci, Warszawa 2011.

35 M. Dąbkowska, Styl atrybucji oraz funkcjonowanie społeczne adolescentów z zespołem nadpobudliwości psychoruchowej z zaburzeniami koncentracji uwagi (ADHD), Torun 2008, s. 29; por. J.H. Scully, Psychiatria, Wrocław 1998.

36 A. Jurek, Jezyki obce w nauczaniu..., op. cit.

37 Dziesiąta rewizja Międzynarodowej Klasyfikacji Chorób i Problemów Zdrowotnych.

38 Preißmann Ch., Zespót Aspergera. Jak z nim żyć. Jak pomagać. Jak prowadzić terapię, Sopot 2012.

39 E. Pisula, Dziecko z zespołem Aspergera, [w:] Dzieci chore, niepetnosprawne i z utrudnieniami w rozwoju, B. Cytowska, B. Winczura, A. Stawarski (red.), Kraków 2008, s. 375-387.

40 P. Randall, J. Parker, Autyzm. Jak pomóc rodzinie, Gdańsk 2004, za A. Kraszewska-Orzechowska, Zachowania dzieci z zespołem Aspergera i proponowane formy pomocy, "Annales Universitatis Mariae Curie-Skłodowska" 2007, vol. XX, s. 47. 
burzeniem ze spektrum autyzmu ${ }^{41}$. Charakterystyczne dla zespołu Aspergera są zaburzenia funkcji społecznych, duży egocentryzm, ograniczone zainteresowania i aktywność, powtarzające się rytuały i rutynowe zachowania, cechy dotyczące mowy i języka (np. monotonny sposób mówienia, perfekcjonizm wypowiedzi, zaburzenia kompetencji dialogowych), problemy z komunikacją pozawerbalną, niezgrabność ruchowa ${ }^{42}$, a także sztywne, ograniczone wzorce zachowania, aktywności i zainteresowań, co przejawia się problemami w rozwoju społecznym i w komunikacji. Jest to szczególnie widoczne w relacjach z rówieśnikami i obejmuje problemy związane ze zdolnością do empatii, rozumienia sytuacji społecznych, zdolnością do społecznego uczenia się, rozumienia abstrakcyjnego znaczenia języka, interpretowania mowy ciała i innych niewerbalnych komunikatów ${ }^{43}$.

Podobnie jak dysleksja, zespół Aspergera nie znika z wiekiem, jednak osoby dorosłe potrafią coraz lepiej kompensować swoje deficyty, mimo że symptomy zaburzenia są u nich nadal widoczne ${ }^{44}$.

Etiologia zespołu Aspergera nie jest znana - wyniki badań neurobiologicznych wskazują na nieprawidłowości w funkcjonowaniu płatów czołowych i ciała migdałowatego, ale wskazuje się również na podłoże genetyczne i czynniki ryzyka, które mogą prowadzić do uszkodzenia mózgu w okresie prenatalnym i okołoporodowym ${ }^{45}$.

Uczeń z zespołem Aspergera może uczęszczać do szkoły ogólnodostępnej lub integracyjnej. Uczeń taki może ubiegać się, o ile jest taka potrzeba, o orzeczenie stwierdzające potrzebę kształcenia specjalnego - szkoły na podstawie stosownego zaświadczenia mogą otrzymać fundusze na dodatkowe zajęcia terapeutyczne ${ }^{46}$.

W przypadku uczniów z zespołem Aspergera bardzo ważna jest indywidualizacja wymagań i metod pracy w zależności od faktycznych trudności i deficytów, z jednoczesnym uwzględnianiem mocnych stron takiego ucznia ${ }^{47}$. Bardzo istotna jest także właściwa edukacja, w ramach której uczeń taki jest wspierany $\mathrm{w}$ procesie uczenia się oraz jest mu zapewniane odpowiednie środowisko szkolne, w którym są uwzględnione jego potrzeby i trudności, co wspo-

\footnotetext{
41 Por. np. U. Frith, Autyzm i zespót Aspergera, Warszawa 2005; T. Attwood, Zespót Aspergera, Poznań 1998.

42 A. Kraszewska-Orzechowska, Zachowania dzieci z..., op. cit.

43 E. Pisula, Dziecko z zespotem..., op. cit., s. 376.

44 Ch. Preißmann, Zespót Aspergera..., op. cit.

45 E. Pisula, Dziecko z zespołem..., op. cit.

46 J. Święcicka, Uczeń z zespołem Aspergera. Praktyczne wskazówki dla nauczyciela, Kraków 2016.

47 G. Jagielska, Dziecko z autyzmem i zespołem Aspergera w szkole i przedszkolu. Informacje dla pedagogów i opiekunów, Warszawa 2010.
} 
może rozwój jego zdolności adaptacyjnych ${ }^{48}$. To ostatnie jest szczególnie ważne w kontekście nauczycieli, często nieprzygotowanych do pracy z takim uczniem, czego sama doświadczyłam w swojej pracy zawodowej - kilka lat temu brałam udział w zorganizowanym przez dyrekcję szkoły specjalnym szkoleniu dla pracujących w niej nauczycieli. Szkolenie to było konieczne ze względu na pracę z dwoma uczniami z zespołem Aspergera i nieznajomością tego zaburzenia wśród nauczycieli.

\section{Podsumowanie}

W powyższej bardzo ogólnej i bardzo krótkiej charakterystyce dwóch grup uczniowskich starałam się zwrócić uwagę na ich coraz większą powszechność, ale przede wszystkim na złożoność i odpowiedzialność pracy nauczyciela $\mathrm{z}$ takimi uczniami. To właśnie na nauczycielu spoczywa obowiązek takiej organizacji pracy na lekcji, która pogodzi potrzeby uczniów bez zaburzeń, uczniów ze zdiagnozowaną dysleksją, uczniów z zespołem Aspergera oraz wszelkich innych grup uczniowskich, którym $\mathrm{w}$ tym opracowaniu nie poświęciłam w ogóle miejsca. Należy pamiętać, że wszyscy ci uczniowie często uczą się w jednej grupie, korzystają z takich samych materiałów glottodydaktycznych, realizują zapisy tej samej podstawy programowej, a na końcu swojej kariery szkolnej podlegają ocenie $\mathrm{w}$ ramach takiego samego egzaminu maturalnego. Istotny jest fakt, że zarówno opisywany tu uczeń z dysleksją, jak i uczeń z zespołem Aspergera, potrzebują innego rodzaju pracy indywidualnej.

W przypadku ucznia z dysleksją pomoc ze strony nauczyciela powinna sprowadzać się przede wszystkim do stosowania się do wymienionych $\mathrm{w}$ opinii poradni psychologiczno-pedagogicznej wskazówek, ale również do większej świadomości tego zaburzenia i wynikającej z niej pomocy na poziomie choćby preparacji materiałów glottodydaktycznych wykorzystywanych przez nauczyciela na lekcji. Świadomy nauczyciel jest w stanie na tej płaszczyźnie, przy stosunkowo niewielkim dodatkowym nakładzie czasu i pracy, wspomóc takiego ucznia.

W przypadku ucznia z zespołem Aspergera indywidualizacja pracy oznacza przede wszystkim konieczność poznania istoty tego zaburzenia, ponieważ niewiedza $\mathrm{w}$ większości przypadków prowadzi do krzywdzącej dla ucznia oceny ze strony nauczyciela i wielu popełnianych przez niego niezamierzonych błędów $\mathrm{w}$ relacjach $\mathrm{z}$ takim uczniem. Ponadto nieocenioną rolę mają do

48 E. Pisula, Dziecko z zespotem..., op. cit. 
odegrania rodzice takiego ucznia. Za przykład niech posłuży choćby sytuacja z mojej praktyki zawodowej, w której rodzice jednego z uczniów z zespołem Aspergera zaraz po przyjęciu go do szkoły przedstawili radzie pedagogicznej samodzielnie wykonany opis zaburzenia i trudności, z jakimi borykało się ich dziecko. Ponadto przedstawili w formie pisemnej swojego rodzaju „instrukcję obsługi" ich dziecka w tych sytuacjach. Takie dokładne i dostosowane do indywidualnych potrzeb tego konkretnego ucznia wskazówki w znacznym stopniu ułatwiły przebieg złożonych relacji uczeń-nauczyciel i całościowe zrozumienie problemu. Bez tak istotnej i świadomej pomocy ze strony rodziców proces dochodzenia do spisanych przez nich wniosków byłby bardzo długi i, niewykluczone, zakończony porażką.

W tym kontekście rola nauczyciela jest nie do przecenienia. To on swoją postawą ma szansę pomóc dzieciom i młodzieży ze specjalnymi potrzebami edukacyjnymi. Właściwie okazana i przemyślana, adekwatna do problemu pomoc może zaowocować kształtowaniem pozytywnego stosunku takich uczniów do samych siebie (a stosunek ten często od najmłodszych lat jest zły), budowaniem poczucia własnej wartości i godności, zanikaniem problemów emocjonalnych itp. ${ }^{49}$ Nauczyciel jest zatem, czy tego chce, czy nie, współodpowiedzialny za kształcenie ucznia, co ma szczególne znaczenie dla uczniów ze specjalnymi potrzebami edukacyjnymi. Dlatego też ważne jest, aby każdy nauczyciel był zainteresowany dokształcaniem się w tych obszarach wiedzy, tak aby łatwiej było mu zrozumieć trudności, z jakimi boryka się uczeń, a także odpowiednio wspomagać go w nauce ${ }^{50}$. Należy również pamiętać, że najlepszą pomocą dydaktyczną dla uczniów ze specjalnymi potrzebami edukacyjnymi jest zapewnienie im możliwości realizowania normalnego, a nie odrębnego, programu nauczania ${ }^{51}$.

\section{Bibliografia}

Andrychowicz-Trojanowska A., Materiał glottodydaktyczny w podręczniku do nauki języka angielskiego dla szkót średnich a jego odbiorca, „Lingwistyka Stosowana” 2015, 14, s. 1-15.

Arabski J., Przedmowa, [w:] Nowe tendencje w glottodydaktyce, J. Arabski (red.), Katowice 1998, s. 5-6.

\footnotetext{
49 D. Werbińska, Dylematy etyczne nauczycieli języków obcych, Warszawa 2009.

50 B. Trochimiak, Model pracy z uczniem ze specjalnymi potrzebami edukacyjnymi w przedszkolu, szkole podstawowej, gimnazjum i szkole ponadgimnazjalnej, [w:] Podniesienie efektywności kształcenia uczniów ze specjalnymi potrzebami edukacyjnymi, Warszawa 2010.

51 K. Sochacka, Specjalne potrzeby i..., op. cit.
} 
Attwood T., Zespót Aspergera, Poznań 1998.

Bogdanowicz K., Dysleksja a nauczanie języków obcych. Przewodnik dla nauczycieli i rodziców uczniów z dysleksja, Gdańsk 2011.

Bogdanowicz M., Specyficzne trudności w czytaniu i pisaniu w świetle klasyfikacji medycznych, psychologicznych i pedagogicznych, "Audiofonologia” 1997, t. X, s. $145-157$.

Bogdanowicz M., Adryjanek A., Uczeń z dysleksja w szkole - poradnik nie tylko dla polonistów, Gdynia 2005.

Bogdanowicz M., Adryjanek A., Rożyńska M., Uczeń z dysleksją w domu. Poradnik nie tylko dla rodziców, Gdynia 2007.

Chudak S., Refleksja nad uczuciami i emocjami towarzyszacymi procesowi uczenia sie a podręczniki do nauki języków obcych, „Lingwistyka Stosowana” 2011, 4, s. 251-266.

Dakowska M., O rozwoju dydaktyki języków obcych jako dyscypliny naukowej, Warszawa 2014.

Dąbkowska M., Styl atrybucji oraz funkcjonowanie społeczne adolescentów z zespołem nadpobudliwości psychoruchowej z zaburzeniami koncentracji uwagi (ADHD), Toruń 2008.

Dykman R.A., Ackerman P.T., Attention deficit disorder and specific reading disability: Separate but often overlapping disorders, "Journal of Learning Disabilities" 1991, 24, s. 96-103.

Frith U., Autyzm i zespół Aspergera, Warszawa 2005.

Gabryś D., Autonomia ucznia w procesie uczenia się języka obcego (badania kwestionariuszowe), [w:] Nowe tendencje w glottodydaktyce, J. Arabski (red.), Katowice 1998, s. 19-29.

Gick C., Fördern Lehrwerke die Autonomie der Lerner?, [w:] Autonomes und partnerschaftliches Lernen. Modelle und Beispiele aus dem Fremd-sprachenunterricht (Sammel band), M. Müller, L. Wertenschlag, J. Wolff (red.), Berlin 1989, s. 163-185.

Grzela K., Uczeń z dysleksją a nauka języka obcego, [w:] Dysleksja rozwojowa. Organizowanie sytuacji edukacyjnej ucznia w szkole $i$ w rodzinie, A. Giermakowska (red.), Kielce 2012, s. 387-395.

Habib M., The neurological basis of developmental dyslexia. An overview and working hypothesis, „Brain” 2000, 123, s. 2373-2399.

Jagielska G., Dziecko z autyzmem i zespołem Aspergera w szkole i przedszkolu. Informacje dla pedagogów i opiekunów, Warszawa 2010.

Jaworska M., Uczeń ze specyficznymi trudnościami w uczeniu się na lekcji języka obcego a ocenianie, "Języki Obce w Szkole" 2013, 4, s. 81-88.

Jaworska M., Nauka języka obcego jako czynnik stymulujacy i ułatwiajacy korygowanie zaburzeń związanych ze specyficznymi trudnościami w uczeniu się, [w:] Trudności w czytaniu i pisaniu - rozważania teoretyczne i praktyczne, I. Pietras (red.), Warszawa 2012, s. 132-147. 
Jaworska-Biskup K., Strategie kognitywne i metakognitywne w nauczaniu języka obcego uczniów ze specyficznymi trudnościami w czytaniu i pisaniu, [w:] Rola językoznawstwa w metodyce nauczania języka obcego, H. Kardela, T. Zygmunt (red.), Chełm 2007, s. 91-97.

Jurek A., Języki obce w nauczaniu uczniów z dysleksją rozwojową. Część I, „Języki Obce w Szkole" 2004, 1, s. 67-72.

Krasowicz-Kupis G., Psychologia dysleksji, Warszawa 2008.

Kraszewska-Orzechowska A., Zachowania dzieci z zespołem Aspergera i proponowane formy pomocy, „Annales Universitatis Mariae Curie-Skłodowska” 2007, vol. XX, s. 43-55.

Lech B., Wspieranie rozwoju dziecka ze specyficznymi trudnościami w nauce czytania i pisania, [w:] Dysleksja rozwojowa. Organizowanie sytuacji edukacyjnej ucznia w szkole i $w$ rodzinie, A. Giermakowska (red.), Kielce 2012, s. 339-347.

Lipowska M., Dysleksja i ADHD. Wspótwystępujace zaburzenia rozwoju. Neuropsychologiczna analiza deficytów pamięci, Warszawa 2011.

Michońska-Stadnik A., Strategie uczenia się i autonomia ucznia w warunkach szkolnych, Wrocław 1996.

Mickiewicz J., Dysleksja rozwojowa. Podstawy diagnozy i terapii, Torun 2011.

Mini-max O DYSLEKSJI, czyli minimum tego, co na ten temat powinni wiedzieć rodzice i nauczyciele ucznia dyslektycznego, by maksymalnie mu pomóc, D. Mielcarek (red.), Warszawa 2006.

Pater-Ejgierd N., Kultura wizualna a edukacja, Poznań 2010.

Pisula E., Dziecko z zespołem Aspergera, [w:] Dzieci chore, niepełnosprawne i z utrudnieniami w rozwoju, B. Cytowska, B. Winczura, A. Stawarski (red.), Kraków 2008, s. 375-387.

Preißmann Ch., Zespół Aspergera. Jak z nim żyć. Jak pomagać. Jak prowadzić terapię, Sopot 2012.

Randall P., Parker J., Autyzm. Jak pomóc rodzinie, Gdańsk 2004.

Scully J.H., Psychiatria, Wrocław 1998.

Sochacka K., Specjalne potrzeby i specyficzne trudności, [w:] Z problematyki ksztatcenia jezzykowego, t. IV, E. Awramiuk (red.), Białystok 2012, s. 179-194.

Święcicka J., Uczeń z zespołem Aspergera. Praktyczne wskazówki dla nauczyciela, Kraków 2016.

Trochimiak B., Model pracy z uczniem ze specjalnymi potrzebami edukacyjnymi w przedszkolu, szkole podstawowej, gimnazjum i szkole ponadgimnazjalnej, [w:] Podniesienie efektywności kształcenia uczniów ze specjalnymi potrzebami edukacyjnymi, Warszawa 2010.

Werbińska D., Dylematy etyczne nauczycieli języków obcych, Warszawa 2009.

Willcutt E.G., Pennington B.F., Psychiatric Comorbidity in Children and Adolescents with Reading Disability, "Journal of Child Psychology and Psychiatry" 2000, 41(8), s. 1039-1048.

Zawadzka E., Nauczyciele języków obcych w dobie przemian, Kraków 2004. 
Zybert J., Strategie uczenia się języka obcego i nauczyciel, [w:] Nauczanie języków obcych w zreformowanej szkole, H. Komorowska (red.), Warszawa 2000, s. 143-151.

\section{Akty prawne}

Rozporzązenie Ministerstwa Edukacji Narodowej i Sportu z dnia 7 września 2004 roku w sprawie warunków i sposobu oceniania, klasyfikowania i promowania uczniów oraz przeprowadzania sprawdzianów i egzaminów w szkołach publicznych, Dz. U. z 2004, nr 199, poz. 2046 z późniejszymi zmianami.

Rozporzadzenie Ministra Edukacji Narodowej z dnia 30 kwietnia 2007 ze zmianami z 17 listopada 2010 r. zmieniające rozporządzenie w sprawie warunków i sposobu oceniania, klasyfikowania $i$ promowania uczniów $i$ stuchaczy oraz przeprowadzania sprawdzianów i egzaminów w szkołach publicznych, Dz. U. 2010 nr 228 poz. 1491.

Ustawa z dnia 26 stycznia 1982 r. „Karta Nauczyciela”, Dz. U. z 2016 r. poz. 1379. 